\title{
The effect of hepatotropic virus $B$ and $C$ on the degree of hyperglycemia and iron overload and the correlation between hyperglycemia and iron overload in hepatitis patients
}

\author{
Zainab Ali Kadhem \\ Department of Medical Chemistry- College of Medicine- Thi- Qar University- Iraq
}

\begin{abstract}
Aims: This study was design to evaluate the effect of hepatotropic virus's types on the degree of hyperglycemia and iron overload and the correlation between hyperglycemia and iron overload in patients with hepatitis B and C.

Methods: Fifty patients infected with hepatitis B and C virus admitted in Al-Hussein teaching hospital /ThiQar governorate, along with fifty healthy individual as a control group for comparison purposes. The study period was from April 2011 to July 2012.

Results: Of these fifty patients 47 were male (94\%) and 3 were female (6\%), out of which $39(78 \%)$ had viral hepatitis B infection and 11 (22\%) had viral hepatitis C infection. The levels of blood glucose $(209.52 \pm$ $55.11 \mathrm{mg} / \mathrm{dL})$ and iron $(386.65 \pm 95.62 \mu \mathrm{g} / \mathrm{dL})$ were significantly elevated in hepatitis patients as compare with the control group $(73.22 \pm 8.30 \mathrm{mg} / \mathrm{dL})$ and $(154.15 \pm 11.18 \mu \mathrm{g} / \mathrm{dL})$ respectively. The concentration of blood glucose was $210.39 \pm 52.37 \mathrm{mg} / \mathrm{dL}$ and $195.84 \pm 64.77 \mathrm{mg} / \mathrm{dL}$ in hepatitis B and C respectively, there is no significant different in blood glucose between HBV and HCV patients. The concentration of iron was $390.88 \pm 114.82 \mu \mathrm{g} / \mathrm{dL}$ and $385.27 \pm 89.87 \mu \mathrm{g} / \mathrm{dL}$ in hepatitis $\mathrm{B}$ and $\mathrm{C}$ respectively, there is no significant different in blood iron between HBV and HCV patients. There is a positive correlation between blood glucose and iron in hepatitis patients.

Conclusion: The fifty hepatitis patients associated with severe hyperglycemia and iron overload and there is no effect of hepatotropic virus types in the severity degree of hyperglycemia and iron overload. There is a positive correlation between levels of glucose and iron.

Finally, this study suggests that the liver damaged in viral infection disease is not due to the virus directly but to metabolic abnormalities, which are associated with infection such as hyperglycemia and iron overload. On other hand, hyperglycemia had a role in the severity of iron overload that is a problem because its exacerbate oxidative stress and could be the underlying mechanism connecting low rate response to antiviral therapy. So screening for glucose and iron abnormalities should be indicate in hepatitis patients and patients must be use suitable drugs before starting the antiviral therapy.
\end{abstract}

Keywords: Hyperglycemia, Iron overload, Hepatitis B virus, Hepatitis C virus 


\section{تأثير فيروس الكبد B و C على درجة فرط السكر والحديد والعلاقة بين فرط السكر وفرط الحديد لدى مرضى التهاب الكبد الفيروسي}

$$
\text { فرع الكيمياء الطبية-كلية الطب- زينب علي كاظمة ذي قار - العراق. }
$$

الخلاصة

الأهداف: صمدت الدراسة الحالية لتحديد تأثير نوع فيروس الكبد على درجة فرط السكر والحديد والعلاقة بين فرط السكر وفرط الحديد لاى

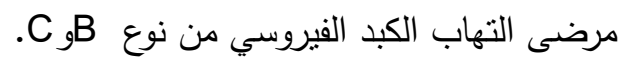

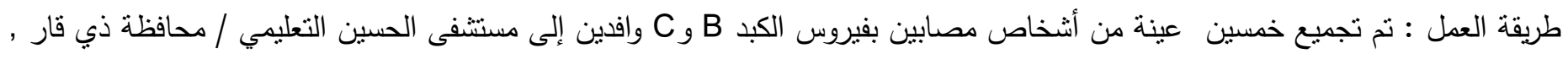

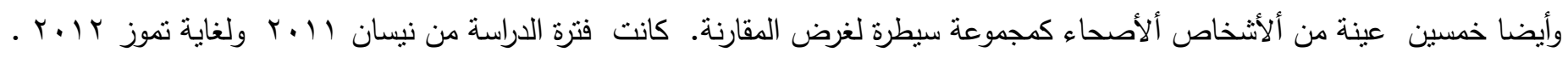

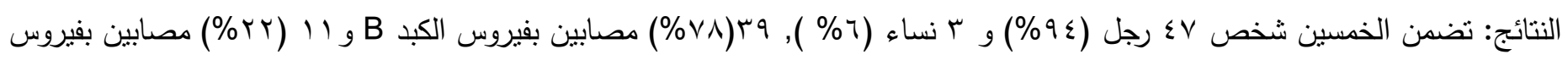
الكبد C . وجد إن مستويات السكر (

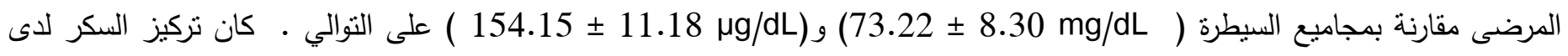

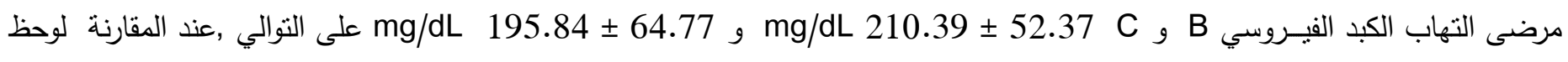

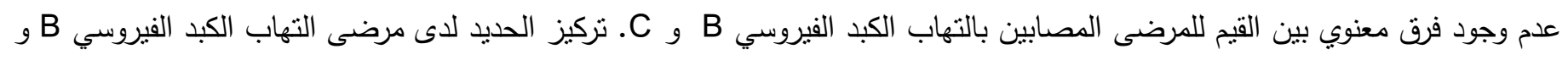

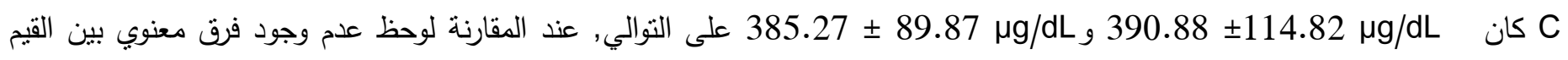
للمرضى المصابين بالتهاب الكبد الفيروسي Cو B. Cما و لوحظ أيضا وجود علاقة طردية بين التغير في مستوى السكر والحديد .

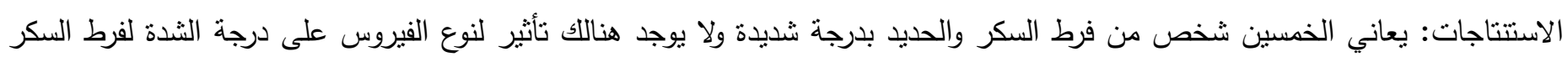
والحديد تنوجد علاقة موجبة بين التغير في مستوى السكر والحديد.

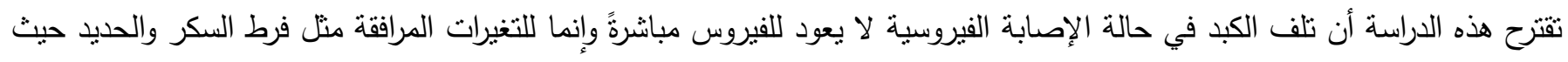

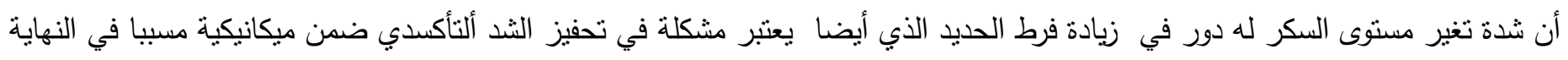

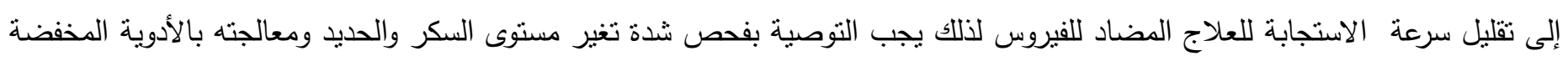

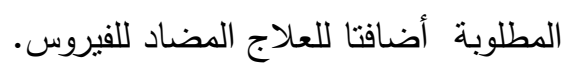
الكلمة المفتاح: فرط السكر , فرط الحديد, التهاب الكبد الفيروسي B, التهاب الكبد الفيروسي C 


\section{Introduction}

Viral hepatitis is a major human health problem worldwide [1]. Viral infections considered to be hepatotropic include viral hepatitis caused by hepatitis viruses $\mathrm{A}, \mathrm{B}, \mathrm{C}, \mathrm{D}, \mathrm{E}$, and $\mathrm{F}$, while the non-hepatotropic are Cytomegalovirus, Herpes Virus, and Epstein-Barr Virus. Most produce an acute infection, and only hepatitis viruses B, C, D, and $\mathrm{E}$ cause chronic liver disease. Many agents are capable of causing liver damage, including drugs, toxins, infections, and metabolic alterations, any of which may lead to liver failure. Viral infection is a frequent cause of liver damage [2]. Several studies have shown that the damage or metabolic changes induced by these viruses have a significant impact on several organs of the body besides the liver [3].

Hepatitis B virus (HBV) is a member of the Hepadnavirus family [4]. Acute infection of HBV in most people can trigger natural immunity to this virus, patients with persistent infection are prone for developing chronic hepatitis, liver cirrhosis, and/or hepatocellular carcinoma (HCC) [5-7]. Generally, It is believed that HBV infection is noncytopathic, with its disease pathogenesis mediated by host innate and adaptive immune responses, as well as other host-virus interactions [8]. The virus HBV spread by contact with an infected person's blood, semen, or other body fluid. $[9,10]$.

The hepatitis $\mathrm{C}$ virus (HCV) is a linear, single-stranded RNA virus of the Flaviviridae family that was identified in 1989 and is recognized as the major causal agent of non-A, non-B hepatitis[11]. It is one of the leading causes of chronic liver disease worldwide, affecting 3\% of the world's population. Diagnosis and treatment of HCV-related autoimmune features has become a clinical challenge in $\mathrm{HCV}$-infected patients, in whom chronic liver disease associated with severe autoimmune features may contribute to a very poor prognosis $[12,13]$.

The HCV characterized by a high replicative potential and a high mutation rate. Due to the diversity of HCV genomes, the virus is classified into 6 genotypes, with several subtypes within each genotype. Chronic hepatitis $\mathrm{C}$ develops in approximately $70-80 \%$ of $\mathrm{HCV}$-infected patients.
HCV replicates mainly in hepatocytes, but its nucleic acids have also been found in peripheral blood mononuclear cells and in central nervous system cells.[14-16]

Hepatitis $\mathrm{C}$ is of concern to both industrialized and developing countries [17]. Hepatitis $\mathrm{C}$ liver disease ranges in severity from a mild illness lasting a few weeks to a serious, lifelong illness that attacks the liver. It is spread primarily through contact with the blood of an infected person [18-20].

Hyperglycemia can impair a wide range of functions in neutrophils and macrophages, including chemotaxis, adherence, phagocytosis, and intracellular killing of microorganisms [17].

Iron is a necessary nutrient; it is need only in small amounts. High levels of iron are associated with an increased risk for cancer, heart disease, and other illnesses such as endocrine problems, arthritis, diabetes, and liver disease [21]. Liver iron accumulation in patients with chronic hepatitis has received increasing attention in recent years [22].

Some authors have found glycemic abnormalities in $\mathrm{HBV}$-infected patients similar to those associated with HCV infection [23] However, others have reported that IR and HBV infection are not related [24,25] and that HBV infection may be protective against the development of IR [26,27] These inconsistencies indicate the need for prospective studies.

This study was design to evaluate the effect of hepatotropic virus's types on the degree of iron overload and hyperglycemia in patients with hepatitis $\mathrm{B}$ and $\mathrm{C}$. These data on the relevance of blood glucose and iron as a prognostic factors prompted us to ascertain whether HCV and HBV related liver damage. Also, evaluate the correlation between hyperglycemia and iron overload in both hepatitis patients.

\section{Patients and methods}

Fifty patients with hepatitis $\mathrm{B}$ and $\mathrm{C}$ virus infection were admitted in Al-Hussein teaching hospital /Thi-Qar governorate, were evaluated retrospectively over a period of 16 months from April 2011 to July 2012, along with fifty healthy 
individual as a control group for comparison purpose.

The diagnosis of HBV and HCV had assayed by enzyme linked immune sorbent assay (ELISA) method, which based on double antibody sandwich technique [28,29]. Assay process performed manually by automatic ELA micro plate immunoanalyzer in the virus's lab at Al Hussein Teaching Hospital Laboratory.

Biochemical analysis of blood sugar and iron had done by using standard common methods [30, 31].

\section{$\underline{\text { Statistical analysis }}$}

Data analyzed by using statistical package for social sciences (SPSS) software version 15. Categorical variables expressed as frequency and percentages. Continuous variables expressed as mean and standard deviation. Continuous variables compared by the t-test. P-values $<0.05$ was considered statistically significant.

\section{Results}

Table 1 and figure 1 show the prevalence of hepatitis according to the gender and virus type. Of these fifty patients 47 were male $(94 \%)$ and 3 were female $(6 \%)$, out of which $39(78 \%)$ had viral hepatitis B infection and $11(22 \%)$ had viral hepatitis $\mathrm{C}$ infection.

Table 1: The prevalence of hepatitis according to the gender and virus type

\begin{tabular}{|c|c|c|c|}
\hline \multirow{2}{*}{ Gender } & \multirow{2}{*}{$\begin{array}{c}\text { Patients } \\
\text { number (\%) }\end{array}$} & $\begin{array}{c}\text { HBV } \\
\text { (\%) }\end{array}$ & $\begin{array}{c}\text { HCV } \\
(\mathbf{\%})\end{array}$ \\
\hline Males & $47(94)$ & $38(76)$ & $9(18)$ \\
\hline Females & $3(6)$ & $1(2)$ & $2(4)$ \\
\hline Total & $50(100)$ & $39(78)$ & $11(22)$ \\
\hline
\end{tabular}

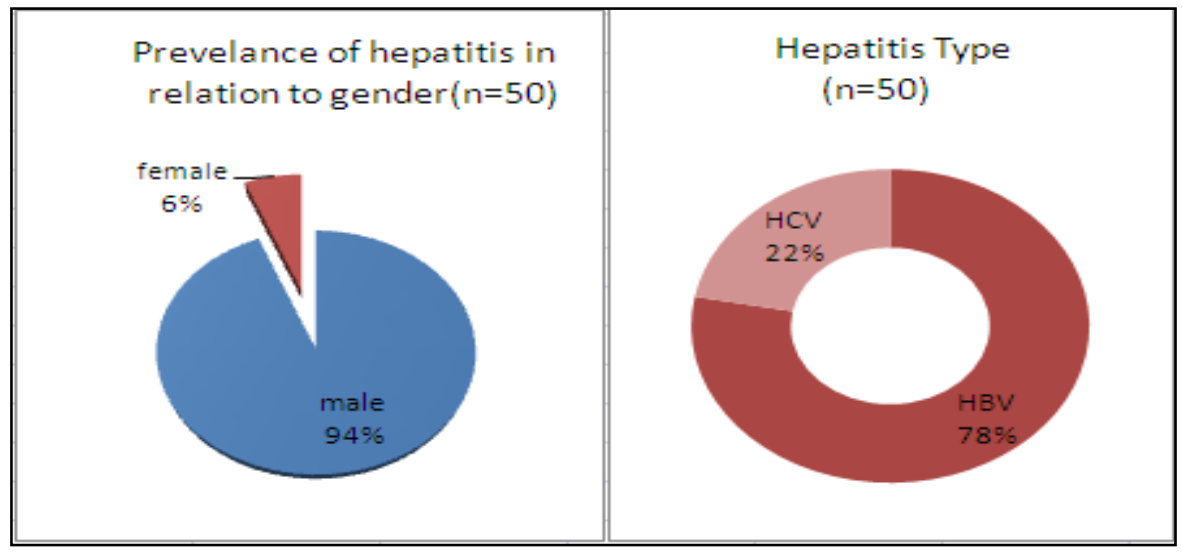

Figure 1: The prevalence of hepatitis in relation to gender of patients and hepatitis type

In table 2 and figure 2 we show the levels of blood glucose and iron in hepatitis patients and healthy controls group. Blood glucose $209.52 \pm 55.11$ $\mathrm{mg} / \mathrm{dL}$ and iron $386.65 \pm 95.62 \mu \mathrm{g} / \mathrm{dL}$ were significantly elevated in hepatitis patients as compare with the control group (73.22 \pm 8.30 $\mathrm{mg} / \mathrm{dL})$ and $(154.15 \pm 11.18 \mu \mathrm{g} / \mathrm{dL})$ respectively. 
Table 2: Changes in blood glucose and iron levels in fifty hepatitis patients and control group

\begin{tabular}{|c|c|c|}
\hline Parameter & $\begin{array}{c}\text { Control } \\
(\mathbf{n = 5 0})\end{array}$ & $\begin{array}{c}\text { Hepatitis } \\
(\mathbf{n}=\mathbf{5 0})\end{array}$ \\
\hline $\begin{array}{c}\text { Glucose }(\mathrm{mg} / \mathrm{dL}) \\
\text { mean } \pm \mathrm{SD} *\end{array}$ & $73.22 \pm 8.30^{\mathrm{a}}$ & $209.52 \pm 55.11^{\mathrm{b}}$ \\
\hline $\begin{array}{c}\text { Iron }(\mu \mathrm{g} / \mathrm{dL}) \\
\text { mean } \pm \mathrm{SD}\end{array}$ & $154.15 \pm 11.18^{\mathrm{a}}$ & $386.65 \pm 95.62^{\mathrm{b}}$ \\
\hline
\end{tabular}

*Each value represents mean \pm SD values with non identical superscript ( $\mathrm{a}, \mathrm{b}$ or $\mathrm{c}$...etc.) were considered significantly different $(\mathrm{P} \leq 0.05)$.

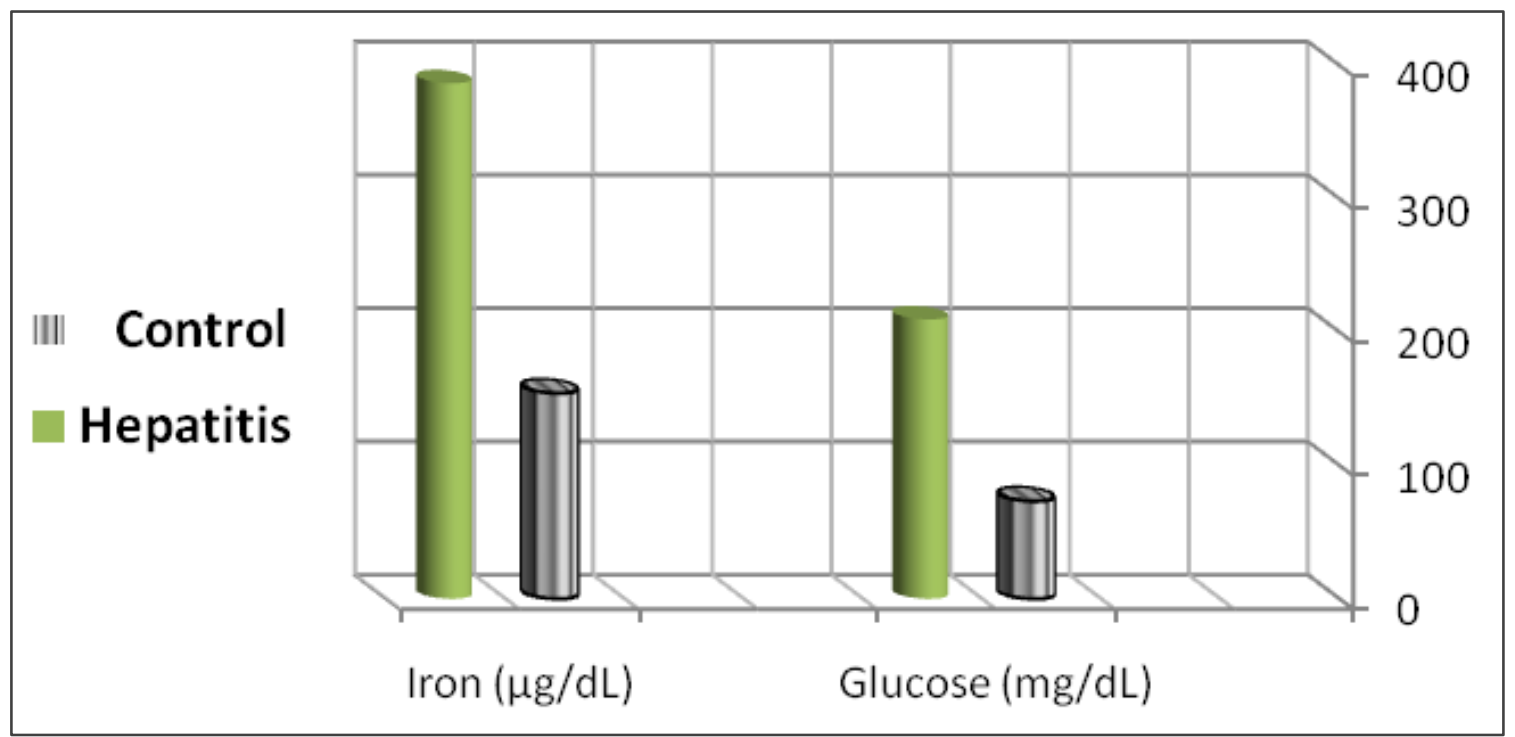

Figure 2: the levels of blood glucose $(\mathrm{mg} / \mathrm{dL})$ and iron $(\mu \mathrm{g} / \mathrm{dL})$ in hepatitis patients and healthy controls group

In table 3 , figure 3 and figure 4 , we can show the concentration of blood glucose and serum iron in both hepatitis patients group.

The concentrations of blood glucose were $210.39 \pm 52.37 \mathrm{mg} / \mathrm{dL}$ and $195.84 \pm 64.77 \mathrm{mg} / \mathrm{dL}$ in hepatitis $\mathrm{B}$ and $\mathrm{C}$ respectively, there is no significant different in blood glucose between $\mathrm{HBV}$ and HCV patients. The concentrations of iron were $390.88 \pm 114.82 \mu \mathrm{g} / \mathrm{dL}$ and $385.27 \pm 89.87$ $\mu \mathrm{g} / \mathrm{dL}$ in hepatitis $\mathrm{B}$ and $\mathrm{C}$ respectively, there is no significant different in blood iron between $\mathrm{HBV}$ and HCV patients.

Table 3: Serum glucose and iron level of fifty hepatitis patients in relation to the type of hepatotropic viruses

\begin{tabular}{|c|c|c|}
\hline Parameters & HBV & HCV \\
\hline Glucose $(\mathrm{mg} / \mathrm{dL})$ mean \pm SD & $210.39 \pm 52.37^{\mathrm{a}}$ & $195.84 \pm 64.77^{\mathrm{a}}$ \\
\hline Iron $(\mu \mathrm{g} / \mathrm{dL})$ mean \pm SD & $390.88 \pm 114.82^{\mathrm{a}}$ & $385.27 \pm 89.87^{\mathrm{a}}$ \\
\hline
\end{tabular}




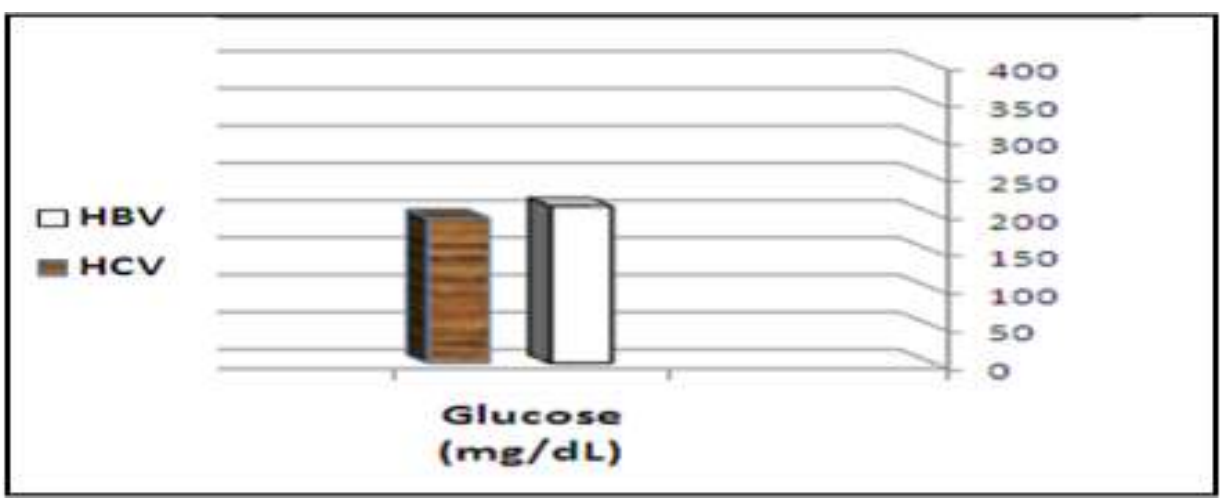

Figure 3: The concentration of blood glucose in both hepatitis patients group

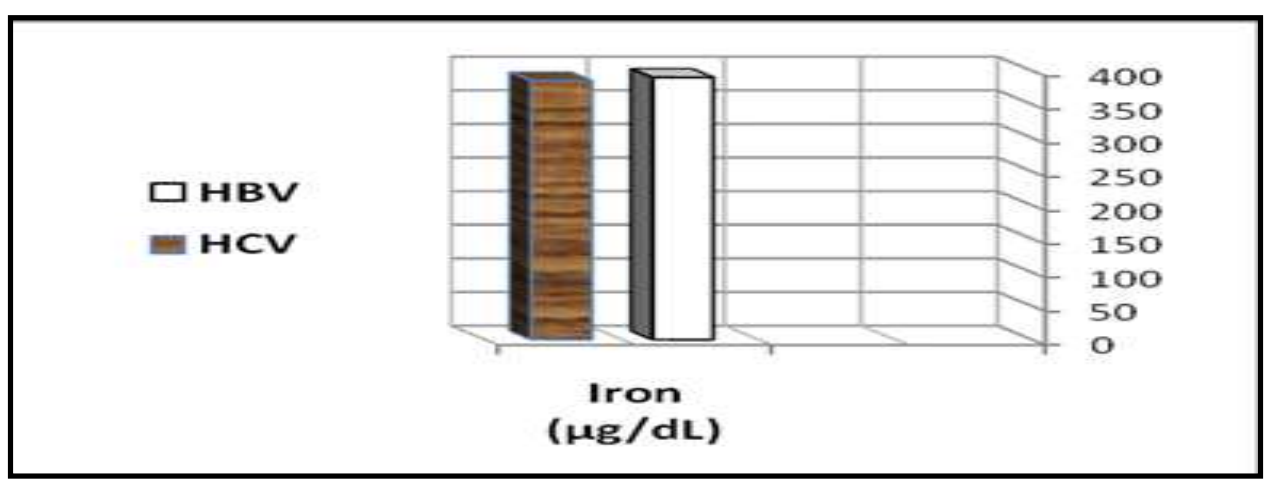

Figure 4: The concentration of serum iron in both hepatitis patients group

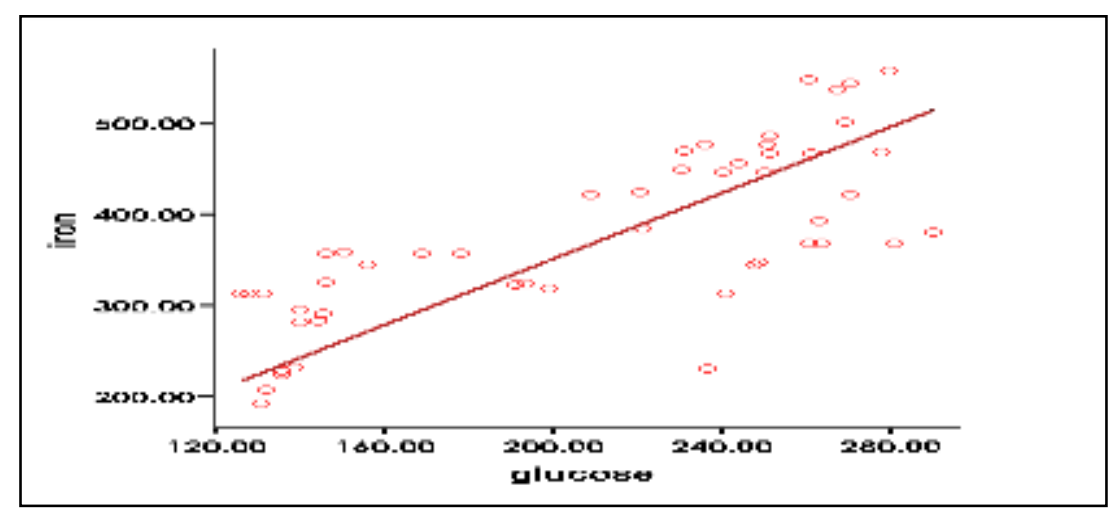

Figure 5: The correlation between hyperglycemia and iron overload

\section{Discussion}

Patients with chronic hepatitis complicated with severe degree of hyperglycemia and insulin resistance (IR). Recent studies have confirmed a close relationship between IR and other liver diseases. Hyperinsulinemia occurs in chronic viral hepatitis $\mathrm{B}$ and $\mathrm{C}$ associate with stage of fibrosis, cirrhosis, liver failure, hepatocellular carcinoma, and a poor response to antiviral therapy against in hepatitis patients because chronic hepatitis is not a single disease, but rather a clinical and pathological syndrome [32-34].

The mechanisms by which hepatic virus produce IR and hyperglycemia are seem that core 
protein increases the synthesis of TNF- $\alpha$, which, at its turn, produces cytokines suppressor of cytokine signaling 3 (SOCS3 ) that inhibit the insulin receptors 1 and 2 (cytokines of phosphorylation), the result being a diminution of the intracellular signal at insulin with the blockage of enzyme GLUT4. GLUT4 is responsible for the access of glucose inside the cell and its blockage directly results into an increased glucose concentration in the blood [35-37]

In 1994, Allison et al described for the first time the correlation between $\mathrm{HCV}$ and type 2 diabetes mellitus (T2DM), [38] although this relationship was found only in cirrhotic patients with HCV. Later studies reported this association in cirrhotic patients with HBV. [39] Subsequent studies found that cirrhosis is not necessary for the development of T2DM because several HCVinfected patients without cirrhosis presented T2DM [40-43]

The association between HBV and the development of hepatic steatosis is also somewhat controversial. Wang and coworkers affirmed that HBV infection is not related to the development of liver steatosis, [44] whereas others have suggested that the accumulation of lipids in the liver occurs through several mechanisms that eventually activate sterol regulatory element binding protein 1 (SREBP-1) and peroxisome proliferator activated receptor- $\gamma(\operatorname{PPAR} \gamma)[45]$.

This last point is interesting because the pathogenesis of HCV associated IR occurs through the inhibition of PPAR $\gamma$ and, as noted, HBV infection produces the exact opposite effect on PPAR $\gamma$. Although other mechanisms responsible for IR development have not been studied thoroughly, this last point may explain the purported protective effect of HBV infection [46]

Iron homeostasis in the human body maintained by mechanisms controlling iron absorption from the intestinal tract, iron recycling from macrophages and mobilization of hepatic iron stores [47].

In humans, carefully regulated system of iron absorption control accompanies by a lack of effective physiological mechanisms for the excretion of excess iron accumulating in different tissues. This is the main reason for progressive iron loading [48].

The reasons for increased iron status in chronic hepatitis may be attributing to a variety of factors. First, hepatocellular damage may cause release of iron in hepatocytes [49], as supported by the finding of positive correlation between ferritin level and transaminase level and by increase level of serum iron as degree of hepatic inflammation increases. Second, chronic liver disease may often be associated with an increased iron absorption in the gastrointestinal tract with marginally elevated hepatic iron [50].

Hepcidin, exclusively synthesized in the liver, is thought to be a key regulator for iron homeostasis and is induced by infection and inflammation suggesting that hepcidin may play a pivotal role in the pathogenesis of iron overload and hyperferritinemia in patients with chronic hepatitis [51].

A new study demonstrates that Stat 3 provides hepato protection against mediated apoptotic liver damage by two mechanisms: direct inactivation of caspases and reduction of reactive oxygen species [52], which is responsible for signaling in inflammation. The iron-induced production of bone morphogenetic proteins (BMPs); one of the multifunctional growth factors with its co-receptor hemojuvelin likely constitutes a key, endogenous signaling pathway for hepcidin activation also through its interaction with IL-6/STAT3 [53]. Hepcidin and its interaction with the transmembrane iron transporter ferroportin (FPN) play crucial roles in the systemic iron balance through down-regulation of iron release from enterocytes and phagocytes [48]. The expression of hepcidin is a complex process, strongly inhibited by hypoxia, anemia, while being activated by inflammation and iron overload. Molecular mechanisms of hepcidin regulation involve stimulation of hepcidin mRNA transcription through the interleukin-6 (IL6)/STAT3 pathway. Stat3 is a vital transcription factor that is activated downstream of the gp130 
receptor, primarily via IL-6 signaling in adult liver [52].

Excess iron increases the formation of reactive oxygen species leading to lipid peroxidation, damage to DNA, thereby to cell membranes and genomic damage. Reactive oxygen species, which include hydroxyl radicals, may cause hepatic stellate cell activation and proliferation and upregulate synthesis of smooth muscle actin and collagen, thus contributing to hepatic fibrogenesis [54-56]. Viral hepatitis and immune-mediated liver damage are believed to occur largely via activation of the Fas apoptotic death pathway. The link between Fas-mediated damage and the induction of reactive oxygen species (ROS) and oxidative damage has only recently been established $[57,58]$.

In vitro studies also suggest that iron deposition in hepatocytes enhances $\mathrm{HCV}$ replication, thus facilitating the viral infection in the liver [59]. Moreover, these hydroxyl radicals known to generate promutagenic bases, such as 8hydroxy-2'-deoxyguanosine (8-OHdG), which have been implicated in spontaneous DNA mutagenesis and carcinogenesis [60].

However, such observation was also reported by Devrajani et al at in Pakistan at 2010 [46] there is no significant different in blood iron between HBV $(390.88 \pm 114.82)$ and HCV (385.27 \pm 89.87$)$ patients.

Although in our study, we had not take the management parameters but it has been reported that iron-restricted diet may be an important therapeutic modality for improving liver injury in patients with chronic hepatitis $C$ [61]. It has been suggested that iron may promote $\mathrm{HCV}$ replication. [51]

Where as a study published in Journal of gastroenterology and hepatology shown similar findings [62]

The increasing in blood glucose is correlated with iron overload due to iron deposition in the interstitial pancreatic cells, with resultant excess collagen deposition and defective microcirculation [63] and insulin resistance [64], are the likely mechanisms for type 2 diabetes.
Mendler in 1999 shows Fe overload may be responsible for insulin resistance, or vice versa [65] also Pietrangelo A. in 2010 suggests an etiologic link between hepatic $\mathrm{Fe}$, hepatic dysfunction, and insulin resistance [63].

Finally, this study suggests that the reason of liver damaged in viral infection disease is not due to the virus directly, but to the severe inflammatory responses associated with the immune response to it and imbalance in the metabolism as glucose and iron.

Hyperglycemia and iron overload could be the underlying mechanism connecting low response rate to antiviral therapy. So screening for glucose and iron abnormalities should be indicated in hepatitis patients and patients must be use suitable drugs in addition to the antiviral therapy.

The information accumulated by this study will help provide a better understanding of involved metabolic processes in order to design appropriate therapeutic approaches for treating these patients and starting antiviral therapy.

\section{References}

1.Jafri, W., N. Jafri, J. Yakoob, M. Islam, S. Farhan, A. Tirmizi, T. Jafar, S. Akthar, S. Hamid, H.A. Shah, S.Q. Nizami, hepatitis b and c: prevalence and risk factors associated with seropositivity among children in Karachi, Pakistan, $b m c$ infectious diseases, 2006, 6, 101-105.

2.Dienstang JL, Isselbacher KJ. Acute viral hepatitis, in: Kasper DL, Braunwald E, Fauci AS, et al. Harrison's Principles of Internal Medicine. McGraw-Hill. 16th ed., 2005, New York, EU: 1825-1855.

3. Hickman IJ, Macdonald GA. Impact of diabetes on the severity of liver disease. Am J Med 2007; 120:829-834.

4. $\wedge \underline{a} \quad \underline{b} \quad \underline{c}$ Zuckerman AJ (1996). "Hepatitis Viruses". In Baron $\mathrm{S}$, et al. Baron's Medical Microbiology (4th ed.). University of Texas Medical Branch. ISBN $\underline{0-}$ 9631172-1-1. 
5.McMahon BJ: The natural history of chronic hepatitis B virus infection. Hepatology 2009, 49(5 Suppl):S45-55.

6. Cougot D, Neuveut C, Buendia MA: HBV induced carcinogenesis. J Clin Virol 2005, 34(Suppl 1):S75-8.

7.Chang JJ, Lewin SR: Immunopathogenesis of hepatitis B virus infection. Immunol Cell Biol 2007, 85(1):16-23.

8.Suzabo G. Pathogenic interactions between alcohol and hepatitis C. Curr Gastroenterol Rep 2003; 5: 86-92.

9. Liu CJ, Jeng YM, Chen CL, et al.: Hepatitis B virus basal core promoter mutation and DNA load correlate with expression of hepatitis B core antigen in patients with chronic hepatitis B. J Infect Dis 199 (5): 742-9, 2009.

10. Marcellin P: Hepatitis $B$ and hepatitis $C$ in 2009. Liver Int 29 (Suppl 1): 1-8, 2009.

11. Choo QL, Kuo G, Weiner AJ, Overby LR, Bradley DW, Houghton M. Isolation of a cDNA clone derived from a blood-borne non-A, non-B viral hepatitis genome. Science. 1989; 244:359-362.

12. Bethlen S, Chandrikakumari $\mathrm{K}$, de Leval L, Giot JB, Mukeba D, Leonard P, Frippiat F, Meuris C, Delwaide J, Moutschen M. Chronic hepatitis $\mathrm{C}$ infection in a patient with bone marrow hypoplasia. World $\mathrm{J}$ Gastroenterol. 2008;14:4238-4240.

13. Trejo O, Ramos-Casals M, García-Carrasco M, Yagüe J, Jiménez S, de la Red G, Cervera R, Font J, Ingelmo M. Cryoglobulinemia: study of etiologic factors and clinical and immunologic features in 443 patients from a single center. Medicine (Baltimore) 2001; 80:252-262.

14. Isom H.C., McDevitt E.I., Moon M.S. (2009) Elevated hepatic iron: a confounding factor in chronic hepatitis C. Biochim. Biophys. Acta 1790: 650-662.

15. Juszczyk J. (2009) Hepatitis C: patogeneza i terapia, Termedia Wydawnictwa Medyczne, Poznań.
16. Levent G., Ali A., Ahmet A., Polat E.C., Aytaç C., Ayşe E., Ahmet S. Oxidative stress and antioxidant defense in patients with chronic hepatitis $\mathrm{C}$ patients before and after pegylated interferon alfa- $2 b$ plus ribavirin therapy. J. Transl. Med. (2006) 4: 25.

17. Lavanchy D: The global burden of hepatitis $C$. Liver Int 29 (Suppl 1): 74-81, 2009.

18. Seeff LB: The history of the "natural history" of hepatitis C. Liver Int (1968-2009) 29 (Suppl 1): 89-99, 2009.

19. Bruno S, Crosignani A, Maisonneuve $P$, et al.: Hepatitis $C$ virus genotype $1 \mathrm{~b}$ as a major risk factor associated with hepatocellular carcinoma in patients with cirrhosis: a seventeen-year prospective cohort study. Hepatology 200746 (5): 1350-6.

20. Persico M, Persico E, Suozzo R, et al.: Natural history of hepatitis $\mathrm{C}$ virus carriers with persistently normal aminotransferase levels. Gastroenterology 118 (4): 760-4, 2000. .

21. Niederau C, Fischer R, Purschel A, Stremmel W, Haussinger D, Strohmeyer G. Longterm survival in patients with hereditary hemochromatosis. Gastroenterology 1996; 110: 1107-19.

22. Ioannou GN, Dominitz JA, Weiss NS, Heagerty PJ, Kowdley KV. Racial differences in the relationship between hepatitis C infection and iron stores. Hepatology 2003; 37:795-801.

23. Custro N, Carroccio A, Ganci A, et al. Glycemic homeostasis in chronic viral hepatitis and liver cirrhosis. Diabetes Metab 2001; 1:476-481.

24. Kumar M, Choudhury A, Manglik N, et al. Insulin resistance in chronic hepatitis $\mathrm{B}$ virus infection. Am $\mathrm{J}$ Gastroenterol 2009; 104:76-82.

25. Wang CC, Hsu CS, Liu CJ, et al. Association of chronic hepatitis B virus infection with insulin resistance and hepatic steatosis. $\mathrm{J}$ Gastroentero Hepatol 2008; 23:779-782.

26. Jas CF, Chen CJ, Chiu YH, et al. A populationbased study investigating the association 
between metabolic syndrome and hepatitis $\mathrm{B} / \mathrm{C}$ infection (Keelung community-based integrated screening study, 10). Int J Obes 2006; 30:794-799.

27. Luo B, Wang Y, Wang K. Association of metabolic syndrome and hepatitis B infection in Chinese population. Clin Chim Acta 2007; 380:238-240.

28. Wei R, knght GJ, Zimmerman DH, and bound HE, Solid -phase enzyme immunoassay for hepatitis B surface antigen. Clin chem.1977, 23:813-815.

29. Esteban JI, Gonzalez A, hernadesz JM et al. Evalution of antibodies to hepatitis $\mathrm{C}$ virus in a study of transfusion associated hepatitis. Nengl JMed 1990:323:1107-12.

30. Trinder, P.A. Clin.Biochem. (1969); 6:24.

31. Horak, hohnadel DC, Sunderman F. W. J. modified method for analysis of serum iron. Ann clin lab sci. 1975; 5(4): 303-307.

32. Mohammad Alizadeh AH, Fallahian $\mathrm{F}$, Alavian SM, Ranjbar M, Hedayati M, Rahimi F, Khedmat H, Etemadi A, Zali MR, Azizi F. Insulin resistance in chronic hepatitis B and C. Indian J Gastroenterol. 2006; 25(6):286-9.

33. Pungpapong S, Kim WR, Poterucha JJ. Natural history of hepatitis B virus infection: an update for clinicians. Mayo Clin Proc. 2007; 82: 967-975.

34. Méndez-S Jnchez N, ChJvez-Tapia NC, Zamora-Valdés D, et al. Hepatobiliary diseases and insulin resistance. Curr Med Chem 2007; 14:1988-1999.

35. Videla L.A., Fernandez V., Tapia G., Varela P. (2003) Oxidative stress-mediated hepatotoxicity of iron and copper: role of Kupffer cells. Biometals 16: 103-111.

36. Cassiman D., Roskans T. (2002) Beauty is in the eye of the beholder: emerging concepts and pitfalls in hepatic stellate cells research. J. Hepatol. 37: 527-535.

37. Hübscher S.G. (2003) Iron overload, inflammation and fibrosis in genetic haemochromatosis. J. Hepatol. 38: 521525.
38. Allison ME, Wreightt $T$, Palmer CR, Alexander GJ. Evidence for a link between hepatitis $\mathrm{C}$ virus infection and diabetes mellitus in cirrhotic population. J Hepatol 1994; 21:1135-1139.

39. Mason AL, Lau JY, Hoang N, et al. Association of diabetes mellitus and chronic hepatitis $\mathrm{C}$ virus infection. Hepatology 1999; 29:328-333.

40. Antonelli A, Ferri C, Fallahi $\mathrm{P}$, et al. Hepatitis $C$ virus infection: evidence for an association with type 2 diabetes. Diabetes Care 2005; 28:2548-2550.

41. Lecube A, HernUndez C, GenescJ J. Diabetes is the main factor accounting for the high ferritin levels detected in chronic hepatitis C virus infection. Diabetes Care 2004; 27:2669-2675.

42. Fraser GM, Harman I, Meller N, Niv $\mathrm{Y}$, Porath A. Diabetes mellitus is associated with chronic hepatitis $\mathrm{C}$ but not chronic hepatitis B infection. Isr J Med Sci 1996; 32:526-530.

43. Mehta SH, Brancati FL, Sulkowski MS, et al. Prevalence of type 2 diabetes mellitus among persons with hepatitis $\mathrm{C}$ virus infection in the United States. Ann Intern Med 2000; 133:592-599.

44. Wang CC, Hsu CS, Liu CJ, et al. Association of chronic hepatitis B virus infection with insulin resistance and hepatic steatosis. J Gastroenterol Hepatol 2008; 23:779-782.

45. Kim KH, Shin HJ, Kim K, et al. Hepatitis B virus $\mathrm{X}$ protein induces hepatic steatosis via transcriptional activation of SREBP1 and PPAR gamma. Gastroenterol 2007, 132:1955-1967.

46. R. devrajani, S. Z. A. Shah, M. Dayo, T. Devrajani, and I. bibi: Serum iron level in patients with chronic viral hepatitis: six months hospital based cross sectional descriptive studyb. pakistan journal of science. 2010: 62: 1.

47. Crichton R.: Iron metabolism - from molecular mechanisms to clinical consequences, Wiley, Chichester: 2009. 
48. Nemeth E., Tuttle M.S., Powelson J., Vaughn M.B., Donovan A., Ward D.M., Ganz T., Kaplan J. Hepcidin regulates cellular iron efflux by binding to ferroportin and inducing its internalization. Science (2004) 306: 2090-2093.

49. Acon BR, Britton RS: The role of the liver in normal iron metabolism. Semin Liver Dis 1984; 4: 181-192.

50. Farinati F, Cardin $\mathrm{R}$, De Maria $\mathrm{N}$ et al: HCV infec-tion correlates with increased serum ferritin, hepatic iron \& lipoperoxidation. Gastroenterol. 1993; 104: 23A.

51. Naoki, F., S. Ryosuke, T. Masaki, U. Naohito, M. Rumi, T. Hideaki, K. Yoshinao, I. Motoh, W. Shozo, A. Yukihiko and K. Masahiko. Hepcidin Expression in the Liver: Relatively Low Level in Patients with Chronic Hepatitis C. Mol Med., 13 (12): 97-104(2007).

52. Del Campo JA, Romero-Gómez M. Steatosis and insulin resistance in hepatitis C: A way out of the virus? World J Gastroenterol 2009; 15:5016-5019.

53. Pietrangelo A. (2010). Hereditary hemochromatosis: pathogenesis, diagnosis, and treatment. Gastroenterology 139: 393408.

54. Ramm GA, Ruddell RG. Hepatotoxicity of iron overload: mechanisms of iron induced hepatic fibrogenesis. Semin Liver Dis 2005; 25:433-449.

55. Rigamonti C, Andorno S, Maduli E, Morelli S, Pittau S, Nicosia G, et al. Iron, hepatic stellate cells and fibrosis in chronic hepatitis C. Eur J Clin Invest 2002;32:2835.

56. Nieto N, Friedman SL, Cederbaum AI. Stimulation and proliferation of primary rat hepatic stellate cells by cytochrome P450 2E1-derived reactive oxygen species. Hepatology 2002; 35:62-73.

57. Pinkoski MJ, Brunner $T$, Green $D R$, Lin $T$. Fas and Fas ligand in gut and liver. Am. J. Physiol. Gastrointest. Liver Physiol. 2000; 278:G354-G366.
58. Jayanthi S, Ordonez S, McCoy MT, Cadet JL. Dual mechanism of Fas-induced cell death in neuroglioma cells: a role for reactive oxygen species. Brain Res. Mol. Brain Res. 1999; 72:158-165.

59. Kakizaki S, Takagi H, Horiguchi $\mathrm{N}$, Toyoda M, Takayama $H$, Nagamine $T$, et al. Iron enhances hepatitis $\mathrm{C}$ virus replication in cultured human hepatocytes. Liver 2000; 20:125-128.

60. Kaito M. Molecular mechanism of iron metabolism and overload in chronic hepatitis C. J Gastroenterol 2007; 42:9699.

61. Iwasa, M., M. Kaito, J. Ikoma, Y. Kobayashi, Y. Tanaka, K. Higuchi, K. Takeuchi, K. Iwata, S. Watanabe and Y. Adachi. Dietary iron restriction improves aminotransferase levels in chronic hepatitis $\mathrm{C}$ patients. Hepatogastroenterology, 2002: 49(44): 529-531.

62. Martinelli, A. L. C., A. B. Araujo, R. F. Franco, M. H. T. Tavella, L. N. Z. Ramalho, S. Zucoloto, S. S. Rodrigues and M. A. Zago. Liver iron deposits in hepatitis B patients: Association with severity of liver disease but not with hemochromatosis gene mutations. J. gastroenterology and hepatology. 2004: 19(9):1036-1041.

63. Agnello V. Therapy for cryoglobulinemia secondary to hepatitis $C$ virus: the need for tailored protocols and multiclinic studies. $J$ Rheumatol 2000; 27: 2065-2067

64. Marchesini G, Brizi M, Bianchi G, Tomassetti S, Bugianesi E, Lenzi M, McCullough AJ, Natale S, Forlani G, Melchionda N. Nonalcoholic fatty liver disease: a feature of the metabolic syndrome. Diabetes 2001; 50: 1844-1850.

65. Nandi SS, Chawla YK, Nath R, Dilawari JB. Serum and urinary zinc in fulminant hepatic failure. J Gastroenterol Hepatol 1989; 4: 209-213. 